\title{
DOI https://doi.org/10.30525/978-9934-26-116-9-27
}

\section{ЗАПОБІГАННЯ ПРАВОПОРУШЕНЬ В СФЕРІ АДМІНІСТРУВАННЯ ПОДАТКУ НА ДОДАНУ ВАРТІСТЬ}

\author{
Логвин А. В. \\ доктор філософії з права \\ м. Дніпро, Україна
}

Заходи адміністративного запобігання належать до числа найпоширеніших серед усіх заходів адміністративного примусу, застосування яких передбачено нормами податкового законодавства. Метою їх застосування $є$ захист інтересів державної економічної безпеки та недопущення вчинення правопорушень, тобто ці заходи мають чітку профілактичну спрямованість.

У теорії адміністративного права науковцями пропонується декілька класифікацій заходів адміністративного примусу. Наприклад, такими науковцями як О. Бандурка, Ю. Битяк, С. Гончарук, С. Ківалов, А. Комзюк підтримується запропонована М. Сропкіним класифікація заходів адміністративного примусу на заходи адміністративного запобігання, заходи адміністративного припинення та заходи адміністративного стягнення [1]. Натомість, І. Галаган відокремлює заходи адміністративної відповідальності, припинення та запобігання [2]. I. Голосніченко та Б. Росинський вважають їх різновидом заходів адміністративного припинення, оскільки вони застосовуються після початку правопорушення з метою його припинення [4].

На нашу думку кожна 3 позицій має свою рацію. Лише зазначимо, що для адміністративного примусу в системі заходів протидії ухиленню від сплати податку на додану вартість (мінімізації податкових зобов'язань, маніпулювання звітністю, та ін.) характерними є саме заходи адміністративного запобігання та протидії.

Протидія ухиленню від сплати податку на додану вартість (уникнення виконання платниками податків свого податкового обов'язку шляхом мінімізації податкових зобов'язань, маніпулювання звітністю, формування незаконного «сумнівного» податкового кредиту, незаконне відшкодування та ін.) є специфічним видом діяльності контролюючих органів у сфері оподаткування, якому приділяється особлива увага та яке включає систему відповідних заходів. Постійний розвиток суспільних відносин у сфері оподаткування в Україні вимагає ефективного застосування заходів адміністративного запобігання 
(протидії) правопорушенням у цій сфері та звісно якісного стану правового регулювання (законодавче підгрунтя) вказаних заходів. Враховуючи наведене, на наш погляд більш логічним є обговорення діяльності контролюючих органів саме як заходів адміністративного запобігання (протидії) ухиленню від сплати податку на додану вартість (далі за текстом - ПДВ).

Незважаючи, що етимологічне значення термінів «запобігання» та «протидія» $є$ різним: перше означає «заздалегідь відвернення чогонебудь небажаного (негативного явища, процесу)», а другий означає «дію спрямовану проти іншої дії, перешкоджання ій̆» [5], на нашу думку їх об'єднання є логічним з точки зору діяльності контролюючих органів, яка полягає не тільки в передбаченні (відверненні) негативних явищ у сфері справляння податків, але й в протидії вже існуючим негативним явищам, або тим які можуть виникнути.

Важливим компонентом, який сприяє досягненню ефективності застосування заходів адміністративного запобігання та конструктивного наповнення, з урахуванням їх відповідності сучасним податковим відносинам, які стрімко розвиваються, є проведення моніторингу можливих ризиків під час справляння податків і зборів (наявної інформації в інформаційних системах органів державної податкової служби, здійснення якого спонукає до детального аналізу можливих наслідків адміністрування податків (досягнення позитивних результатів та надходження коштів до Державного бюджету) та відповідно відвернення (запобігання та протидія) випадків ухилення від сплати податків, зокрема, податку на додану вартість (мінімізації податкових зобов'язань, маніпулювання звітністю, формування незаконного «сумнівного» податкового кредиту, незаконне відшкодування та ін.).

До вказаних заходів можна віднести запровадження моніторингу відповідності податкових накладних/розрахунків коригування критеріям оцінки ступеня ризиків, достатніх для зупинення реєстрації податкової накладної/розрахунку коригування в Єдиному реєстрі податкових накладних (далі за текстом - СМ КОР, Система) [6] [7] [8].

Зважаючи на міжнародний досвід, запобігання випадкам не сплати ПДВ, уникнення фіктивного його відшкодування, визначення ризикових платників податків вже під час проведення процедури їх реєстрації платниками податку на додану вартість, як один 3 можливих засобів боротьби з цією проблемою, є нормою для багатьох країн Європи [3]. Разом з цим слід звернути увагу, що в СС для боротьби із зловживаннями у сфері ПДВ (податковим шахрайством) використовуються такі програми як Fiscalis [9] та VIES [10]. Вказані програми дозволяють національним податковим адміністраціям створювати та обмінюватись 112 
інформацією та досвідом роботи. Але проведення моніторингу ризиків, на кшталт того, який застосовується в Україні ними не здійснюється.

В свою чергу, слід підкреслити, що автоматизований моніторинг відповідності податкових накладних/розрахунків коригування критеріям оцінки ступеня ризиків є заходом адміністративного запобігання, направленим на запобігання (протидію) ухиленню від сплати податку на додану вартість, який не достатньо врегульований із правової точки зору. Зазначене дає можливості для контролюючих органів на власний розсуд вирішувати питання щодо ризиковості платника податку та ризиковості здійснення операцій, а несумлінним платникам податків для маніпулювання наявними документами.

Заходи адміністративного запобігання (протидії), які використовуються контролюючими органами, є в певному сенсі інструментами, за допомогою яких досягається можливість своєчасного реагування на діяльність платників податків, направлену на ухилення від сплати податків. Визначення таких інструментів $є$ логічним, оскільки діяльність контролюючих органів полягає не тільки в передбаченні (відверненні) негативних явищ у сфері справляння податків, але й в протидії вже існуючим негативним явищам, або тим які можуть виникнути. При цьому, в першому випадку маємо попередження можливих правопорушень (ухилення від сплати податків), яке на нашу думку досягається як за рахунок проведення профілактичних заходів, так і за рахунок якісної законодавчої бази (податкового законодавства), яка регулює сферу оподаткування (усунення правових колізій, неоднозначного тлумачення). В другому випадку - це направлення зусиль на усунення існуючих негативних явищ, або нових, тих, які можуть виникнути в майбутньому з урахуванням не можливості своєчасного їх попередження, тобто, створення умов за яких вони не зможуть набути поширення та відповідне подальше їх усунення.

Автоматизований моніторинг є складовою електронного адміністрування податку на додану вартість та може розглядатись як захід запобігання, відповідно до якого контролюючими органами виявляються операції платників податків, направлені на формування незаконного «сумнівного» податкового кредиту (впливає на мінімізацію податкових зобов'язань та формування від'ємного значення з податку на додану вартість, за яким в подальшому може бути отримано бюджетне відшкодування), а прийняття рішень про відповідність платника податку на додану вартість критеріям ризиковості платника податку та відповідно подальше блокування реєстрації податкових накладних вказаних платників є заходом протидії ухилення від сплати податку на додану 
вартість (припинення розповсюдження незаконного «сумнівного» податкового кредиту).

3 правової точки зору правовий механізм заходів адміністративного запобігання (протидії), зокрема щодо здійснення автоматизованого моніторингу, повинен спонукати уникненню правових колізій та суперечностей, які виникають між контролюючими органами та платниками податків. Може бути дієвим засобом податкового контролю, з метою недопущення схем маніпулювання податковими зобов'язаннями та податковим кредитом, за умови належного правового підгрунтя.

\section{Література:}

1. Адміністративне право України : [підручник] / за заг.ред. О.М. Бандурки. - Харків : Вид-во Нац. ун-ту внутр. справ, 2004. - 480 с.

2. Адміністративне право України : підручник / Ю.П. Битяк, B.М. Гаращук, О.В. Дьяченко та ін. - К. : Юрінком Інтер, 2005. C. 170-202.

3. Андрющенко І.С., Гринь Ю.В. Міжнародний досвід організації податкового адміністрування. Ефективна економіка. 2015. № 11. URL: http://nbuv.gov.ua/UJRN/efek_2015_11_42 (дата звернення 20.02.2021).

4. Голосніченко I. П. Перспективні положення кодифікації норм правового інституту адміністративної відповідальності. Право України. 2007. № 7. С. 60-63.

5. Всесвітній словник української мови. URL: https://uk.worldwidedictionary.org (дата звернення 20.02.2021).

6. Про внесення змін до Податкового кодексу України щодо покращення інвестиційного клімату в Україні. : Закон України від 21.12.2016 р. № 1797-VIII. URL: https://zakon.rada.gov.ua/laws/ show/1797-19\#Техt (дата звернення 20.02.2021).

7. Про затвердження Порядків 3 питань зупинення реєстрації податкової накладної/розрахунку коригування в Єдиному реєстрі податкових накладних. : Постанова Кабінету Міністрів України від 11.12.2019 р. № 1165. URL: https://www.kmu.gov.ua/npas/prozatverdzhennya-poryadkiv-z-pita-a1165 (дата звернення 20.02.2021).

8. Про затвердження Порядку прийняття рішень про реєстрацію/відмову в реєстрації податкових накладних/розрахунків коригування в Єдиному реєстрі податкових накладних. : Наказ Міністерства фінансів України від 12.12.2019 р. № 520. URL: https://zakon.rada.gov.ua/laws/show/z1245-19\#Text (дата звернення 20.02.2021). 
9. The Fiscalis 2020 Programme. URL: https://ec.europa.eu/taxation_ customs/fiscalis-programme_en. (дата звернення 20.02.2021).

10. VIES (VAT Information Exchange System) enquiries. URL: https://ec.europa.eu/taxation_customs/business/vat/eu-vat-rules-topic/ vies-vat-information-exchange-system-enquiries_ en. (дата звернення 20.02.2021).

\title{
DOI https://doi.org/10.30525/978-9934-26-116-9-28
}

\section{FOREIGN CRIMINAL LEGISLATION ABOUT VIOLATION OF THE COMPETITION ORDER}

\author{
Lukianets V.S. \\ PhD in Law, Associate Professor, Professor of the Department \\ of Constitutional Law and Human Rights \\ of the National Academy of Internal Affairs \\ Kyiv, Ukraine
}

This theses analyzes the provisions of domestic legislation on violations of the competition order of such countries as the United States of America (hereinafter - the USA), Germany and France. The antimonopoly legislation of these countries was the basis for the adoption of laws in the field of antimonopoly regulation in Ukraine and in a number of other states.

In above-mentioned countries, competition protection activity is a separate sphere, an independent function of the state, which is regulated by separate normative legal acts and authorities called to implement measures to protect competition.

In the US antitrust legislation, criminal law measures prevail. The first US antitrust law is the Sherman Act, passed by Congress in 1890. The adoption of this kind of Act was associated with the accelerated development of industry after the civil war between the North and South of the United States. Its basic principles are outlined in the first articles [1]. In particular, in accordance with art. 1, agreements and associations in the form of a trust or other form, as well as conspiracy to restrict the development of trade or industry between different US states or foreign states are illegal. This article provides for this type of alternative sanction such as a fine or imprisonment for no more than 10 years. 